\begin{tabular}{|l|l|l||}
\hline \multicolumn{2}{|c|}{ PublisherInfo } \\
\hline \hline PublisherName & $:$ & BioMed Central \\
\hline \hline PublisherLocation & $:$ & London \\
\hline \hline PublisherImprintName & $:$ & BioMed Central \\
\hline \hline
\end{tabular}

\title{
Offspring from infertile parents?
}

\begin{tabular}{|l|c|l||}
\hline \multicolumn{2}{|c|}{ ArticleInfo } \\
\hline \hline ArticleID & $:$ & 4496 \\
\hline \hline ArticleDOI & $:$ & $10.1186 /$ gb-spotlight-20020605-01 \\
\hline \hline ArticleCitationID & $:$ & spotlight-20020605-01 \\
\hline \hline ArticleSequenceNumber & $:$ & 162 \\
\hline \hline ArticleCategory & $:$ & Research news \\
\hline ArticleFirstPage & $:$ & 1 \\
\hline \hline ArticleLastPage & $:$ & 2 \\
\hline \hline & & RegistrationDate : 2002-6-5 \\
\hline ArticleHistory & $:$ & OnlineDate \\
\hline \hline ArticleCopyright & $:$ & BioMed Central Ltd2002-6-5 \\
\hline \hline ArticleGrants & $:$ & \\
\hline \hline ArticleContext & $:$ & 130593311 \\
\hline \hline
\end{tabular}




\section{Jonathan B Weitzman}

Email: jonathanweitzman@hotmail.com

Twenty percent of people who try to conceive experience fertility problems and up to half of these may be due to impaired spermatogenesis. In the May 28 Proceedings of the National Academy of Sciences Masahito Ikawa and colleagues at The Salk Institute describe a gene therapy approach that may one day be applied to treat infertility (Proc Natl Acad Sci USA 2002, 99:7524-7529). The complex cellular and molecular interactions that regulate spermatogenesis rely on contact between germ cells and somatic Sertoli cells. Ikawa et al. exploited a mouse model characterized by Sertoli cell dysfunction due to mutations in the gene encoding c-Kit ligand. They tested a number of gene therapy vectors (including adenovirus, adeno-associated virus and retroviruses) before choosing lentiviral vectors to deliver a gene

encoding functional c-Kit ligand. Transduction into mice testes resulted in expression in the Sertoli cells, but no germ line transmission. Viral delivery rescued spermatogenesis, and Ikawa et al.demonstrated that these sperm could be successfully used to generate normal offspring by intracytosplamic sperm injections.

\section{References}

1. Proceedings of the National Academy of Sciences, [http://www.pnas.org]

2. The Salk Institute, [http://www.salk.edu]

3. The kit-ligand (steel factor) and its receptor c-kit/W: pleiotropic roles in gametogenesis and melanogenesis. 